\title{
The Major Challenges Faced by Middle Class People of Dhaka City in Coronavirus Pandemic Period: A Multivariate Analysis
}

\author{
Asma Akter ${ }^{1, *}$ and Md. Ashadujjaman ${ }^{2}$ \\ 1,*Department of Economics, Asian University of Bangladesh, Dhaka, Bangladesh and ${ }^{2}$ Department \\ of Sociology and Anthropology, Asian University of Bangladesh, Dhaka, Bangladesh \\ Email of corresponding author: akterasma73@yahoo.com
}

\begin{abstract}
At present, Covid-19 pandemic creates a vulnerable situation for all over the world. This situation is highly effects on all of the social and economic aspects. Dhaka is the capital city of Bangladesh which is the world's six most densely populated city. The most of the people of Dhaka city are middle class who has been facing different types of challenges due to Corona pandemic situation. The objective of this study is to identify the challenges that has faced by middle class people at Dhaka city of Bangladesh. Questionnaire and interview techniques were used to collect the data of this study. Both descriptive and inferential statistics were used to analyze the data. Descriptive statistics were used to give details about the Corona virus as well as inferential statistics were used to identify the major challenges and show the significant relationship between Covid-19 pandemic and identified challenges which has faced by middle class people at Dhaka city. Factor analysis was used to identify the major challenges that are created by corona virus pandemic situation. Multivariate analysis of variance was used to show that the overall and individual significant effect of Covid19 pandemic on identified major challenges. Findings of the study show that there are six challenges which are reasonably formed by this circumstance. The identified major challenges are Financial crisis that has led to increase child marriages and divorce due to increase family conflict, Failure to meet basic needs that led to increase child labor, Unemployment rates and occupational changes have increased, Decreased social interaction which led to increase psychological and physical complications among children and adults, Decreased financial ability to meet the cost of education and Frustration grows among the people that increased deviant behavior in the society. The findings of this study may help the concerned line organizations to take necessary steps to overcome the situation of middle class people of Dhaka city in Bangladesh.
\end{abstract}

Keywords: COVID-19; Middle Class People; Major Challenges; Dhaka City; Bangladesh; Multivariate Analysis.

\section{INTRODUCTION}

Coronavirus disease (COVID-19) is an infectious disease caused by the SARS-COV-2 virus. (WHO, 2020). It spread all over the world very quickly. It is not only impacting public health but also impacts the social and economic aspects. Around 232,608,482 cases have been found in the world where 4,762,082 million people have died till now due to corona virus. (Worldometer, September 27, 2021). Bangladesh has faced a vulnerable situation in this issue. The present outbreak of covid-19 statistics in Bangladesh is 1,551,351 cases has detected where dead statistics is 27,414 (Coronavirus COVID-19 Dashboard, September 27, 2021). To control the outbreak of COVID-19 disease, the Bangladesh government has imposed some restrictions and has taken several attempts like lockdown, shutdown, etc when many social and economic activities were completely stopped. Dhaka, the capital city in Bangladesh where the population is now estimated at 21,741,090, with a density of 23,234 people per square kilometer within a total area of 300 square kilometers. (World Population Review, 2021). The outbreak of coronavirus was more in Dhaka city than the others areas of Bangladesh. The middleclass people of Dhaka city have faced more challenges rather than the other classes of people due to the coronavirus pandemic circumstances. Closure of workplace and education institutions, worried about health security and money, cramped living conditions, isolations with peers, neighbor and relatives, movement restrictions, deserted public spaces made urban people life more challenging.

There are some studies that have been conducted about the impact of the COVID-19 pandemic situation. Literature reviews demonstrate that mental stress created due to the COVID-19 because of the lockdown without ensuring the fundamental needs of the vulnerable ones. The poor governance in the healthcare systems and the facilities further exacerbates the general public's 
anxiety. The urban COVID-19 testing facilities, long serial to be tested, lowest facilities in the dedicated hospital units for COVID-19 patients hampered the other critical patients to get healthcare services. (Shammi, M., et al. 2020). A small-scale quantitative overview about the impact on socioeconomic condition in lockdown wards of Khulna City Corporation (KCC), Bangladesh due to this pandemic. With the socioeconomic stress of COVID-19, people's satisfaction level is measured with well-known index life scale assessment to measure the judgmental component of subjective well-being. (Haque, M. N, et al. 2020). With proper intervention, the epidemic progression can be controlled in a graceful manner. An important question is whether the tests being performed by Bangladesh are enough. The ideal number of tests for Bangladesh should be more than 3-fold. However, in such a case, the epidemic progression can be controlled with proper interventions. (Khan, I.M., et al. 2020). A significant rise in the poverty rate and a projected shortfall in the country's GDP compared to the previous years. In the last ten years, GDP growth in Bangladesh has been strong, reaching an annual growth rate of $7.9 \%$ in 2019. In 2020 Bangladesh GDP was projected to fall to $2 \%$ due to economic downturns resulting from COVID-19 economic lockdowns (IMF 04/2020). For the last 15 years, Bangladesh's poverty rate had steadily reduced from 40 percent in 2005 to $21.8 \%$ in 2017-2018 and 20.5 percent in 2019 (Dhaka tribune 08/2020; BBS 2019). Since the start of 2020, the General Economic Division's estimation reported that Bangladesh's poverty rate has risen to $29.5 \%$ as of June 2020 (a 9\% increase from $20.5 \%$ in the 2018/2019 fiscal year), highlighting a decline in Bangladesh's socio-economic growth. The aftermath of the COVID-19 pandemic is likely to be millions of people pushed back into extreme poverty in 2020 , especially people working in the informal economy, whose incomes dropped significantly since the start of the pandemic. This will make the achievement of Sustainable Development Goals (SDG) in Bangladesh even more challenging. (USAID, November Report 2020). COVID-19 has already impacted RMG workers' health (both physical and mental health status) and wellbeing, and resulted in loss of employment. (Kabir, H., et al. 2020). There is a lower-middle-income economy with one of the world's densest populations in Bangladesh. Social distancing is difficult in many areas of the country, and with the minimal resources the country has, it would be extremely challenging to implement the mitigation measures. Mobile sanitization facilities and temporary quarantine sites and healthcare facilities could help mitigate the impact of the pandemic at a local level. (Anwar, S., et al. 2020). The spread of the COVID-19 pandemic, the partial lockdown, the disease intensity, weak governance in the healthcare system, insufficient medical facilities, unawareness, and the sharing of misinformation in the mass media has led to people experiencing fear and anxiety. In society, Psychosocial and Socio-Economic Crisis of COVID-19 has created psychosocial and socioeconomic insecurity among people due to the loss of lives and livelihoods. (Bodrud-Doza et al, 2020). Prevalence estimates of depression, anxiety and stress (DAS) were, respectively, 76.1\%, 71.5\% and $70.1 \%$ for at least mild symptoms, $62.9 \%, 63.6 \%$ and $58.6 \%$ for at least moderate symptoms, $35.2 \%$, $40.3 \%$, and $37.7 \%$ for at least severe symptoms and $19.7 \%, 27.5 \%$ and $16.5 \%$ for at least very severe symptoms. The present estimates of DAS were more prevalent than in previous pre-COVID-19 studies among Bangladeshi university students. (Islam, M. S., et al. 2020) . The substantial labor market impacts both at the extensive and intensive margin, with important variation across areas and gender, largely due to the nature of occupations affected by the crisis and substantial uncertainty about job prospects. (Genoni, M.E., et al. 2020). Socio-demographics and questions about knowledge and preventive behaviors related to COVID-19. Participants' being male, being divorced or widowed, consuming alcohol, smoking cigarettes, living in villages, and having no formal education reported lower performing preventive COVID-19 behaviors. Those participants with higher knowledge scores reported higher preventive COVID-19 behaviors. (Hosen, I., et al. 2021). The current economic situation may seriously undermine the livelihood of the underprivileged cohort of the population. To overcome this situation, the integrated effort from the state authority as well as concern people of all sectors need to come forward. (Begum, M., et al. 2020). The daily wage rates as Bangladesh Taka (BDT) 272.2 in the farm sector and BDT 361.5 in the nonfarm sector. Using the estimated daily wage earnings, this study estimates that a one-day complete lockdown generates a US \$64.2 million equivalent economic loss only considering the 
wage loss of the daily wage workers. After estimating the daily per capita food expenditure separately for farm and nonfarm households, this study estimates a minimum compensation package for the daily wage-based farm and nonfarm households around the US \$ 1 per day per household to ensure minimum food security for the daily wage-based worker households. (Mottaleb, K.A., et al. 2020) .

The above-stated studies focused on the impacts of covid-19 virus on psychological and physical condition of people and socioeconomic aspects of Bangladesh. Some study has conducted about the impact of the covid-19 pandemic on education sector. Few researchers discussed about the limitation of the health sector during coronavirus pandemic situation. None of the studies focus on a social class people or the people of a specific area who have been facing massive challenges in their daily life in the period of corona pandemic. This study would try to identify the major challenges that have been facing middle-class people of Dhaka city due to the coronavirus pandemic situation. This study also tries to investigate the relationship between covid-19 pandemic and major challenges.

\section{OBJECTIVES}

The overall objective of this study is to examine the challenges has been facing by middle class people at Dhaka city in Bangladesh at the time of coronavirus pandemic. The specific objectives of the study are listed below:

1. To identify the major challenges that has been facing by the middle class people of Dhaka city at the time of COVID-19 pandemic situation.

2. To show the significant relationship between this pandemic and identified challenges.

\section{METHODOLOGY OF THE STUDY}

This study attempt to investigate the impact of COVID -19 on middle class people of Dhaka city in Bangladesh. Primary sources of data were used to perform this study which was collected from respondents through direct interview.

\subsection{DETERMINATION OF SAMPLE SIZE}

This study includes the conscious people of Dhaka city for its population. At present, there have around 2,17,41,090 people in Dhaka city of Bangladesh. We determined our sample size from approximate 10000000 conscious people of Dhaka city. Random sampling technique was used to select respondents for this inquiry. The sample can be determined by using the following formula suggested by Yamane (1967) with 5 percent sampling error. The formula used in this study is given away below.

$n=\frac{N}{1+N(e)^{2}}$

Where, $\mathrm{n}=$ Sample Size

$\mathrm{N}=$ Population

$\mathrm{e}=$ Percentage of sampling error

(1) Population size is $>10000000$ people

(2) Percentage of sampling error is 5\%

In calculating the sample size the subsequent assumptions were made to find out, $\mathrm{n}=399$.

\subsection{SAMPLE SUFFICIENCY TEST AND SPHERICITY TEST}

Table 1 gives information about the hypothesis of factor analysis. The sample sufficiency index KMO by Kaiser-Meyer-Olkin has identified which compares the sizes of the observes correlation coefficients to the sizes of the partial correlation coefficient for the sum of analysis variables is 87.5 percent and it is reliable because it is above 80 percent. In addition, supposition test of sphericity by the Bartlett's Test (H0: All correlation coefficients are not quite far from zero) is rejected on a level of statistical significance $p<0.05$ for approx. For these data, Bartlett's Test is highly significant $(\mathrm{p}<0.001)$. As a result, both acceptances for the conduct of factor analysis are satisfied and we can carry on with it.

Table 1: KMO and Bartlett's Test

\begin{tabular}{|lll|}
\hline \multicolumn{2}{|l}{ Kaiser-Meyer-Olkin Measure of } \\
Sampling Adequacy & $\mathbf{0 . 8 7 5}$ \\
Bartlett's & Approx. Chi-Square & 3054.945 \\
Test of & df. & 351 \\
Sphericity & Sig. & .000 \\
\hline
\end{tabular}




\subsection{SAMPLE DISTRIBUTION}

To perform this study 399 respondents were interviewed from Dhaka city of Bangladesh. We selected our respondents both male and female. Details of sample distribution are given in the following figures.

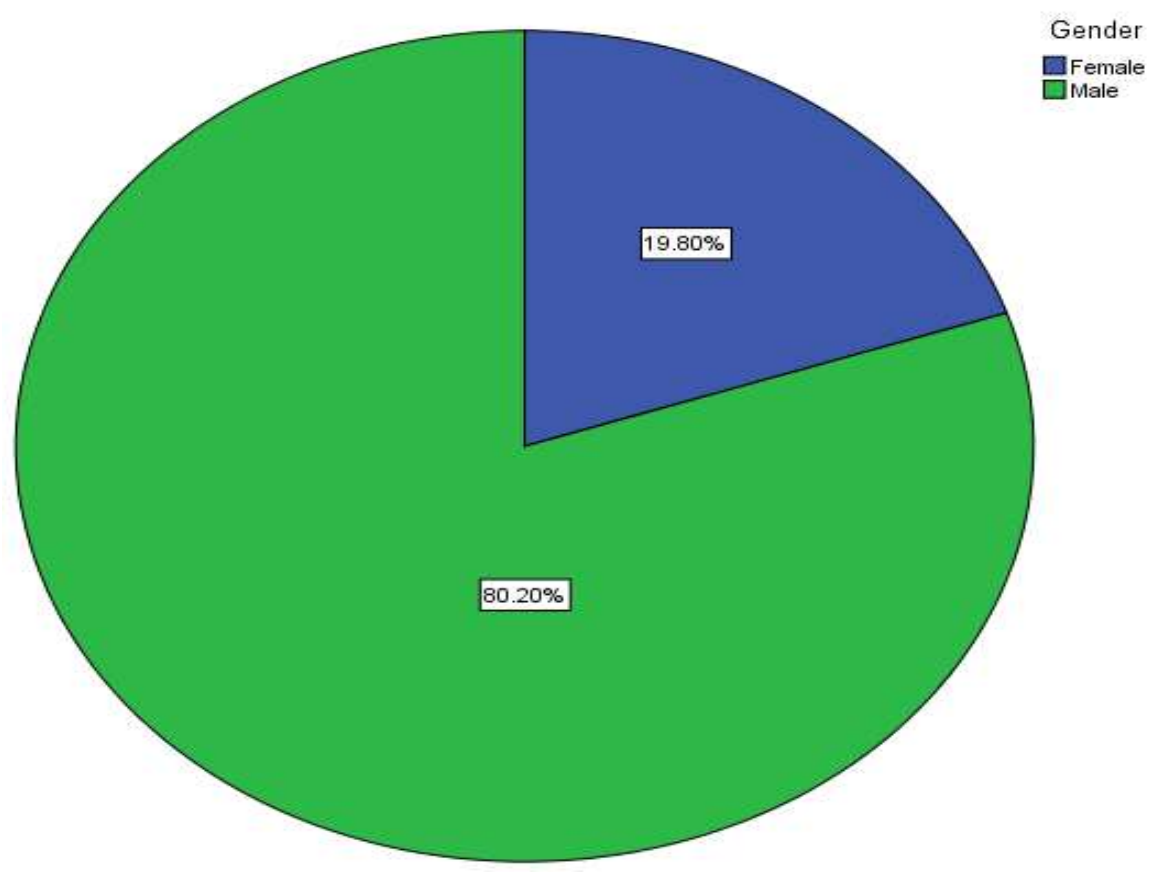

Figure 1: Gender wise sample distribution

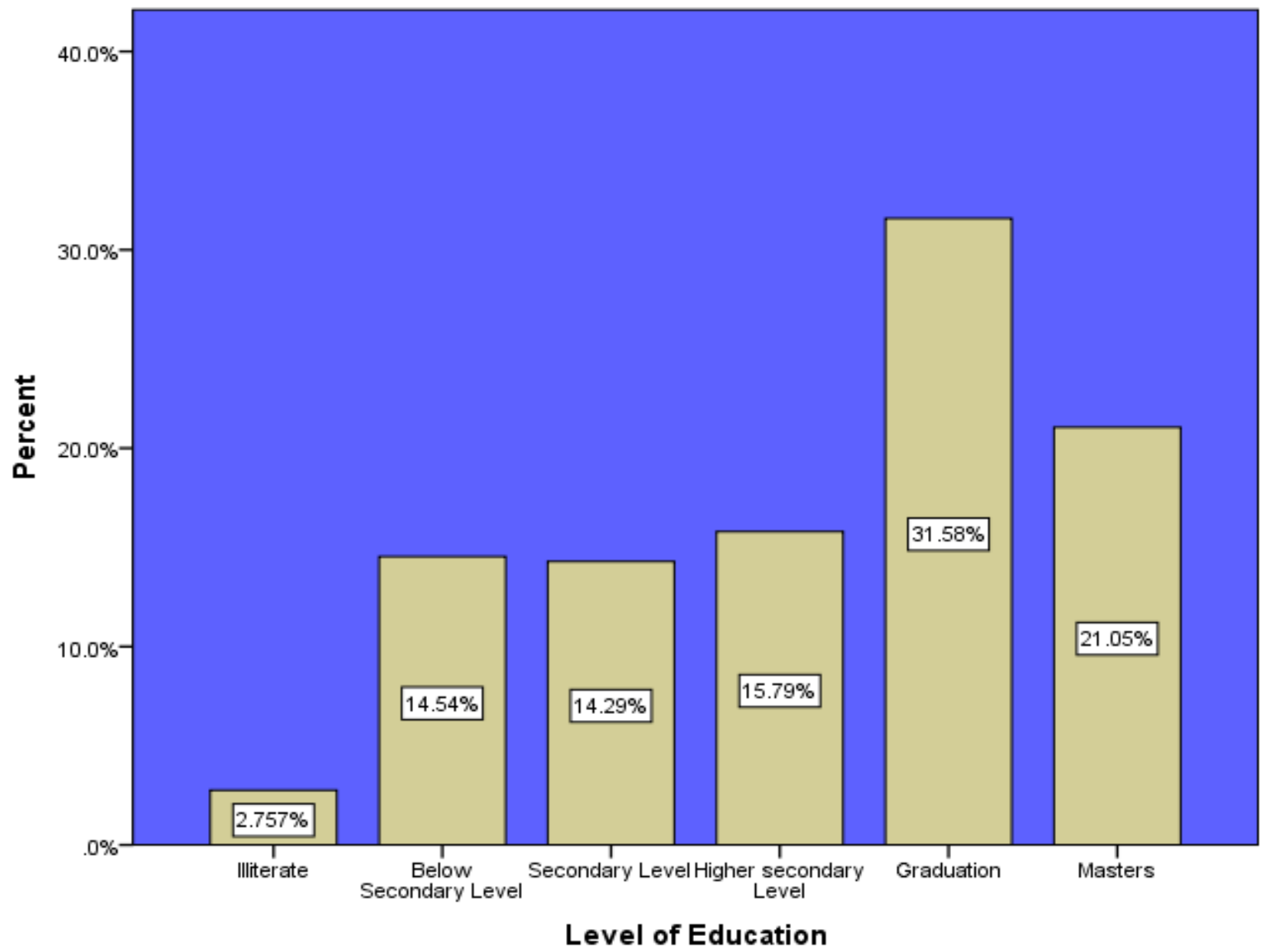

Figure 2: Education level wise sample distribution. 


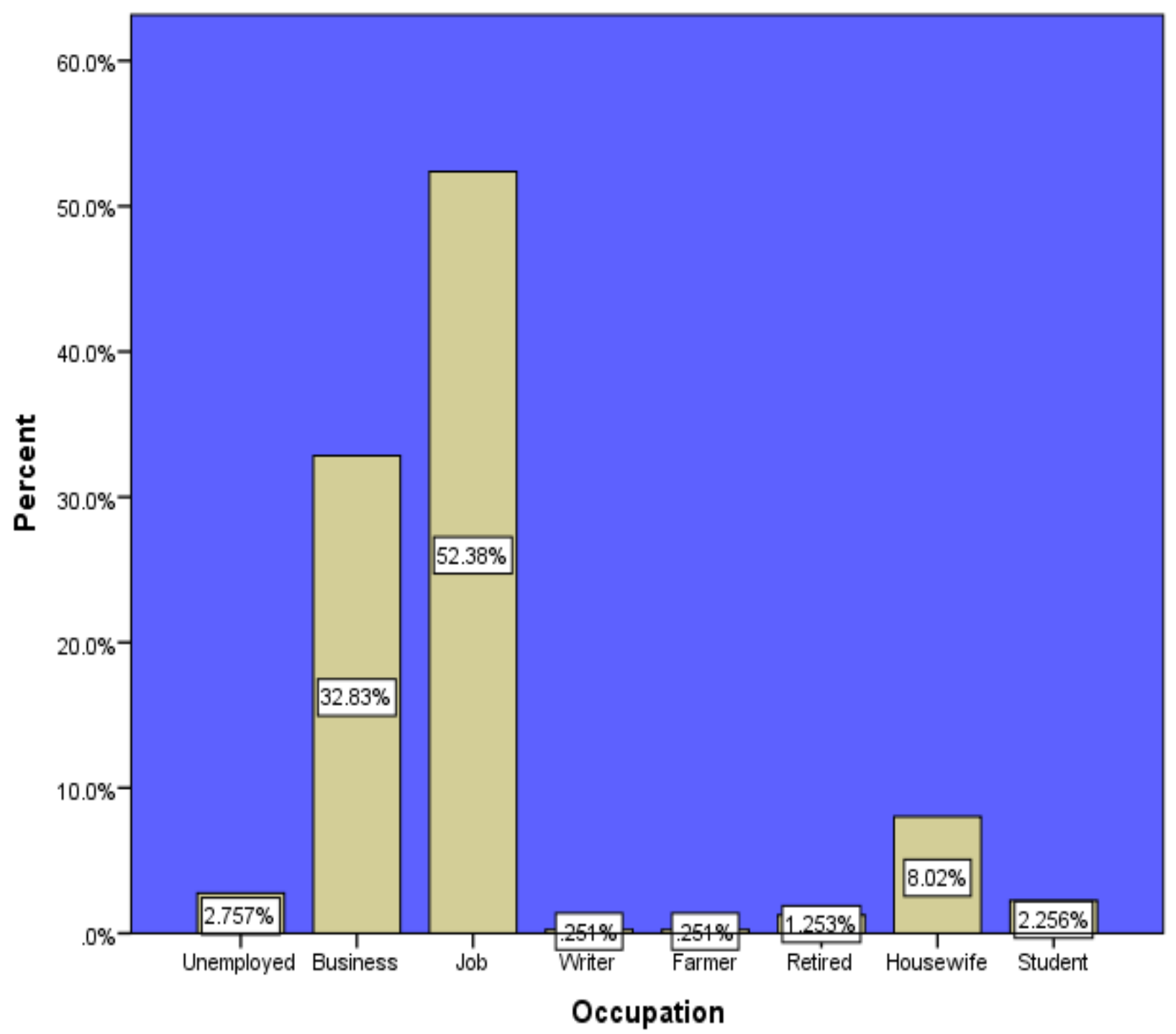

Figure 3: Occupation wise sample distribution.

\subsection{QUESTIONNAIRE SETUP AND TEST OF RELIABILITY}

The questionnaire of this study was considered with Likert scale method. Likert scale questionnaire was designed with 5 point scales which range from 5 to 1 where 5 is indicating strongly agree and 1 is indicating strongly disagree. Table 2 shows the reliability coefficient of the questionnaire. It shows that the Cronbach's alpha of the questionnaire is 0.873 which is excellently acceptable as per Nunnally (1978).

\section{Table 2: Reliability Statstics}

\section{Cronbach's Alpha Number of Items 0.873 27}

The questionnaire of the study setup with the following challenges of middle class people at
Dhaka city of Bangladesh which are suffered by this pandemic situation. The considered challenges are lost job, increased unemployment, change of profession, decreased income, financial crises, migration, the ability of the middle class to meet the cost of education has decreased, reduced basic needs, decreased calorie intake, declined standard of living, fallen into the vicious cycle of debt, decreased purchasing power, fallen below the poverty line, increased family unrest, enhanced child marriage, risen divorced, the tendency to commit suicide has increased, social distance increased, enlarged frustration, become mentally deranged, youth to engage in socially deviant behaviors, savings have declined, education gap has increased, child labor is increased, increased mental illness, aggravated children's addiction to video games and the internet and the responsibilities towards parents and relatives have decreased. 


\subsection{DATA COLLECTION TECHNIQUES}

A survey has been performed on $80.20 \%$ male and $19.80 \%$ female respondents at the Dhaka city of Bangladesh. All the data of this study were collected by interview through the questionnaire with random sampling technique. The interviewers were bachelor and masters students of Economics Department of Asian University of Bangladesh. Interviewers were appropriately trained on the matters representing the questionnaire for data collection before resuming the interview. This research was carried out from April 2021 to August 2021.

\subsection{DATA ANALYSIS METHODS}

This study was used some inferential statistical method for data analysis. Factor analysis in SPSS (Statistical Package for Social Sciences) program was used to reduce the items or affected factors related to the coronavirus pandemic situation in Dhaka city of Bangladesh. Multivariate Analysis of Variance (MANOVA) was used to show the overall and individual significant effect of independent variable on dependent variables for developing a model of this study.

\section{RESULTS OF THE STUDY}

The two methods were used to identify the findings of the study have been divided into two divisions such as (i) Factor analysis and (ii) Multivariate analysis of variance (MANOVA). Factor analysis identified six major challenges which are created through corona pandemic situation at Dhaka city in Bangladesh. The result shows that the communalities of the variables are reasonably high (The average communality is grater then 0.5 ) which are indicating the variables used in the data set are reasonably cohesive in nature (Appendix 1). The most important identified challenges are financial crisis has led to increase child marriages and divorce due to increase family conflict ( $24.794 \%$ ), failure to meet basic needs which reduced daily calorie intake that led to increase child labor (9.329\%), Unemployment rates and occupation changes have increased and the big number of people in debt has enhanced (5.379\%), Decreased social interaction which led to increase psychological and physical complications among children and adults $(4.735 \%)$ , Decreased financial ability of middle class people to meet the cost of education $(4.371 \%)$ and frustration grows among the people that increased deviant behavior in the society $(3.735 \%)$ as shown in Table 3.

Table 3: Total Variance Explained

\section{Component}

1. Financial crisis has led to increase child marriages and divorce due to increase family conflict

2. Failure to meet basic needs which reduced daily calorie intake that led to increase child labor

3. Unemployment rates and occupation changes have increased and the big number of people in debt has enhanced

4. Decreased social interaction which led to increase psychological and physical complications among children and adults

5. Decreased financial ability of middle class people to meet the cost of education

6. Frustration grows among the people that increased deviant behavior in the society

\section{Initial Eigenvalues}

Total

6.694

2.519

1.452

$\%$ of

Variance

24.794

9.329

5.379

39.501

1.278

4.735

44.236

1.180

4.371

48.607

1.008

3.735

52.342 
Multivariate analysis of variance (MANOVA) indicating that the major challenges identified through the factor analysis are altogether significantly influenced by coronavirus pandemic situation at Dhaka city of Bangladesh. The output of MANOVA has two segments. The first part is Multivariate tests

Table 4: Multivariate Tests $^{\mathrm{a}}$

\begin{tabular}{|c|c|c|c|c|c|c|c|c|c|}
\hline \multirow[t]{2}{*}{ Effect } & & $\begin{array}{l}\text { Val } \\
\text { ue }\end{array}$ & $\mathbf{F}$ & $\begin{array}{l}\text { Hypothesi } \\
\text { s df }\end{array}$ & $\begin{array}{l}\text { Error } \\
\text { df }\end{array}$ & Sig & $\begin{array}{l}\text { Partial } \\
\text { Eta } \\
\text { square } \\
\text { d }\end{array}$ & $\begin{array}{l}\text { Noncent. } \\
\text { Paramete } \\
\text { r }\end{array}$ & $\begin{array}{l}\text { Observed } \\
\text { Power }^{\text {d }}\end{array}$ \\
\hline & Pillai's Trace & $\begin{array}{l}.08 \\
7\end{array}$ & $6.184^{\mathrm{b}}$ & 6.000 & 390.000 & .00 & .087 & 37.106 & .999 \\
\hline \multirow{3}{*}{$\begin{array}{l}\text { Inter } \\
\text { cept }\end{array}$} & $\begin{array}{l}\text { Wilks' } \\
\text { Lambda }\end{array}$ & $\begin{array}{l}.91 \\
3\end{array}$ & $6.184^{\mathrm{b}}$ & 6.000 & 390.000 & .00 & .087 & 37.106 & .999 \\
\hline & $\begin{array}{l}\text { Hotelling's } \\
\text { Trace }\end{array}$ & $\begin{array}{l}.09 \\
5\end{array}$ & $6.184^{\mathrm{b}}$ & 6.000 & 390.000 & .00 & .087 & 37.106 & .999 \\
\hline & $\begin{array}{l}\text { Roy's Largest } \\
\text { Root }\end{array}$ & $\begin{array}{l}.09 \\
5\end{array}$ & $6.184^{\mathrm{b}}$ & 6.000 & 390.000 & .00 & .087 & 37.106 & .999 \\
\hline \multirow{4}{*}{$\begin{array}{l}\text { COV } \\
\text { ID- } \\
19\end{array}$} & Pillai's Trace & $\begin{array}{l}.81 \\
1\end{array}$ & 24.193 & 18.000 & $\begin{array}{l}1176.00 \\
0\end{array}$ & .00 & .270 & 435.481 & 1.000 \\
\hline & $\begin{array}{l}\text { Wilks' } \\
\text { Lambda }\end{array}$ & $\begin{array}{l}.22 \\
7\end{array}$ & 42.191 & 18.000 & $\begin{array}{l}1103.57 \\
2\end{array}$ & .00 & .390 & 704.478 & 1.000 \\
\hline & $\begin{array}{l}\text { Hotelling's } \\
\text { Trace }\end{array}$ & $\begin{array}{l}3.2 \\
32\end{array}$ & 69.777 & 18.000 & $\begin{array}{l}1166.00 \\
0\end{array}$ & .00 & .519 & 1255.994 & 1.000 \\
\hline & $\begin{array}{l}\text { Roy's Largest } \\
\text { Root }\end{array}$ & $\begin{array}{l}3.1 \\
80\end{array}$ & $\begin{array}{l}207.750 \\
\mathrm{c}\end{array}$ & 6.000 & 392.000 & .00 & .761 & 1246.498 & 1.000 \\
\hline
\end{tabular}

a. Design: Intercept + Overall

b. Exact Statistic

c. The statistic is an upper bound on $\mathrm{F}$ that yields a lower bound on the significance level

d. Computed using alpha $=0.5$

These results (from Table 4) show that there is a significant effect of the covid-19 on the middle class people of Dhaka city who are facing these challenges. There is no one single multivariate test; there are four different ones. In this case, they are all significant $(\mathrm{p}<0.05)$, as a result, we can conclude that covid-19 have a significant effect on altogether of identified major challenges faced by middle class people of Dhaka city in Bangladesh.

The second part of the results is univariate tests. The results of the univariate tests used for the effect of COVID-19 pandemic on individual identified major challenges.

Table 5: Tests of Between-Subjects Effects

\begin{tabular}{|c|c|c|c|c|c|c|c|c|c|}
\hline Source & $\begin{array}{l}\text { Dependent } \\
\text { Variable }\end{array}$ & $\begin{array}{l}\text { Type } 3 \\
\text { Sum of } \\
\text { Squares }\end{array}$ & df & $\begin{array}{l}\text { Mean } \\
\text { Square }\end{array}$ & $\mathbf{F}$ & Sig. & $\begin{array}{l}\text { Partial } \\
\text { eta } \\
\text { squared }\end{array}$ & $\begin{array}{l}\text { Noncent } \\
\text { parameter }\end{array}$ & $\begin{array}{l}\text { Observed } \\
\text { Power }\end{array}$ \\
\hline $\begin{array}{l}\text { Corrected } \\
\text { Model }\end{array}$ & $\begin{array}{l}\text { 1.Financial } \\
\text { crisis has led } \\
\text { to increase } \\
\text { child } \\
\text { marriages and } \\
\text { divorce due to } \\
\text { increase } \\
\text { family } \\
\text { conflict }\end{array}$ & $62.919^{a}$ & 3 & 20.973 & 24.724 & .000 & .158 & 74.171 & 1.000 \\
\hline
\end{tabular}


2.Failure to meet basic needs which reduced daily calorie intake that led to increase child labor

3.Unemployment rates and occupation changes have increased and the big number of people in debt has enhanced

4.Decreased social interaction which

Corrected Model led to increase psychological and physical $27.145^{\mathrm{d}}$ complications among children and adults

5.Decreased financial ability of middle class people to meet the cost of education

6.Frustration grows among the people that increased deviant behavior in the society

1. Financial crisis has led to increase child marriages and divorce due to increase family conflict

2.Failure to meet basic needs which Intercept reduced daily calorie intake that led to increase child labor

3.Unemployment rates and occupation changes have increased and the big number of people in debt has enhanced $\begin{array}{llllllll}63.049^{\mathrm{b}} & 3 & 21.016 & 24.784 & .000 & .158 & 74.352 & 1.000\end{array}$

$\begin{array}{llllllll}67.766^{\mathrm{c}} & 3 & 22.589 & 27.019 & .000 & .170 & 81.057 & 1.000\end{array}$

$\begin{array}{llllllll}74.720^{\mathrm{e}} & 3 & 24.907 & 30.432 & .000 & .188 & 91.297 & 1.000\end{array}$

$\begin{array}{llllllll}27.063^{\mathrm{f}} & 3 & 9.021 & 9.606 & .000 & .068 & 28.818 & .997\end{array}$

$\begin{array}{llllllll}3.461 & 1 & 3.461 & 4.080 & .044 & .010 & 4.080 & .522\end{array}$

$\begin{array}{llllllll}3.245 & 1 & 3.245 & 3.827 & .051 & .010 & 3.827 & .497\end{array}$

$\begin{array}{llllllll}3.576 & 1 & 3.576 & 4.277 & .039 & .011 & 4.277 & .541\end{array}$ 
4.Decreased social interaction which led to increase psychological and physical 1.87 complications among children and adults

Intercept

5.Decreased financial ability of middle class people to meet the cost of education

6.Frustration grows among the people that increased deviant behavior in the society

1. Financial crisis has led to increase child marriages and divorce due to increase family conflict

2.Failure to meet basic needs which reduced daily calorie intake that led to increase child labor

3.Unemployment rates and occupation changes have increased and the big number of people in

COVID- debt has enhanced

19

4.Decreased social interaction which led to increase psychological and physical complications among children and adults

5.Decreased financial ability of middle class people to meet the cost of education

6.Frustration grows among the people that increased deviant behavior in the society

1. Financial crisis has led to increase child

Error marriages and divorce due to increase family conflict

\begin{tabular}{|c|c|c|c|c|c|c|c|}
\hline .841 & 1 & .841 & .895 & .345 & .002 & .895 & .157 \\
\hline 62.919 & 3 & 20.973 & 24.724 & .000 & .158 & 74.171 & 1.000 \\
\hline 63.049 & 3 & 21.016 & 24.784 & .000 & .158 & 74.352 & 1.000 \\
\hline 67.766 & 3 & 22.589 & 27.019 & .000 & .170 & 81.057 & 1.000 \\
\hline 27.145 & 3 & 9.048 & 9.637 & .000 & .068 & 28.912 & .998 \\
\hline 74.720 & 3 & 24.907 & 30.432 & .000 & .188 & 91.297 & 1.000 \\
\hline 27.063 & 3 & 9.021 & 9.606 & .000 & .068 & 28.818 & .997 \\
\hline 335.081 & 395 & .848 & & & & & \\
\hline
\end{tabular}

$\begin{array}{llllllll}3.750 & 1 & 3.750 & 4.582 & .033 & .011 & 4.582 & .570\end{array}$

$\begin{array}{llllllll}.877 & 1 & 1.877 & 1.999 & .158 & .005 & 1.999 & .292\end{array}$ 
2.Failure to meet basic needs which reduced daily calorie intake that led to increase child labor

334.951395 .848

3.Unemployment rates and occupation changes have increased and the big number of people in debt has enhanced

330.234

395

.836

Error 4.Decreased social interaction which led to increase psychological and physical complications among children and adults

5.Decreased financial ability of middle class people to meet the cost of education

323.280

395

.818

6.Frustration grows among the people that increased deviant behavior in the society

$370.937 \quad 395$

1. Financial crisis has led to increase child marriages and divorce due to increase family conflict

398.000

399

2.Failure to meet basic needs which reduced daily calorie intake that led to increase child labor

398.000

399

3.Unemployment rates and occupation changes have increased and the big number of people in debt has enhanced

Total

4.Decreased social interaction which led to increase psychological and physical complications among children and adults

5.Decreased financial ability of middle class people to meet the cost of education

398.000

399

6.Frustration grows among the people that increased deviant behavior in the society

398.000

399

1. Financial crisis has led to increase child marriages and divorce due to increase family conflict

398.000

398

2.Failure to meet basic needs which reduced daily calorie intake that led to increase child labor

398.000

398

3.Unemployment rates and occupation changes have

Correct increased and the big number of people in debt has enhanced

ed

Total
4.Decreased social interaction which led to increase psychological and physical complications among children and adults

5.Decreased financial ability of middle class people to meet the cost of education

6.Frustration grows among the people that increased deviant behavior in the society
$398.000 \quad 398$

$398.000 \quad 398$

$398.000 \quad 398$

$398.000 \quad 398$

a. R Squared $=.158$ (Adjusted R Squared $=.152$ )

b. $\mathrm{R}$ Squared $=.158$ (Adjusted R Squared $=.152$ )

c. R Squared $=.170($ Adjusted R Squared $=.164)$

d. $\mathrm{R}$ Squared $=.068$ (Adjusted R Squared $=.061)$

e. $\mathrm{R}$ Squared $=.188$ (Adjusted R Squared $=.182)$

f. $\mathrm{R}$ Squared $=.068$ (Adjusted R Squared $=.061$ )

g. Computed using alpha $=.05$ 
These univariate tests ( shown above Table 5) indicated that COVID -19 has a significant effect on individual identified major challenges such as, Financial crisis has led to increase child marriages and divorce due to increase family conflict $\{\mathrm{F}(3$, 395) $=24.724 ; \mathrm{p}=0.000 ;$ Partial $\left.\eta^{2}=0.158\right\}$, Failure to meet basic needs which reduced daily calorie intake that led to increase child labor $\{\mathrm{F}(3,395)=$ 24.784; $\mathrm{p}=0.000$; Partial $\left.\eta^{2}=0 \quad .158\right\}$, Unemployment rates and occupation changes have increased and the big number of people in debt has enhanced $\{\mathrm{F}(3,395)=27.019 ; \mathrm{p}=0.000$; Partial $\left.\eta^{2}=0.170\right\}$, Decreased social interaction which led to increase psychological and physical complications among children and adult $\{\mathrm{F}(3,395)$ = 9.637; $\mathrm{p}=0.000 ;$ Partial $\left.\eta^{2}=0.068\right\}$, Decreased financial ability of middle class people to meet the cost of education $\{\mathrm{F}(3,395)=30.432 ; \mathrm{p}=0.000$; Partial $\left.\eta^{2}=0.188\right\}$, and Frustration grows among the people that increased deviant behavior in the society $\left\{\mathrm{F}(3,395)=9.606 ; \mathrm{p}=0.000\right.$; Partial $\eta^{2}$ $=0.068\}$.

\section{DISCUSSION CONCLUSIONS}

AND

The main purpose of the study was to identify major challenges which are caused by coronavirus pandemic situation at Dhaka city of Bangladesh.

\subsection{SUMMARY OF THE FINDINGS}

After analyzing the data our study has got some findings. Factor analysis has identified six factors that generated by COVID- 19 pandemic situation. The identified major challenges are financial crisis has led to increase child marriages and divorce due to increase family conflict ( $24.794 \%$ ), failure to meet basic needs which reduced daily calorie intake that led to increase child labor (9.329\%), unemployment rates and occupation changes have increased and the big number of people in debt has enhanced (5.379\%), Decreased social interaction which led to increase psychological and physical complications among children and adults (4.735\%)
, Decreased financial ability of middle class people to meet the cost of education $(4.371 \%)$ and frustration grows among the people that increased deviant behavior in the society $(3.735 \%)$. The 6 factors as a whole $52.342 \%$ significantly influenced by this pandemic situation at Dhaka city in Bangladesh. Multivariate analysis of variance (MANOVA) shows two types of results. The first one is Multivariate tests shows that COVID-19 have a significant effect on altogether of the identified six major challenges which tackled by middle class people at Dhaka city of Bangladesh. The 2nd part is univariate tests which indicated that corona epidemic has the significant effect on individual identified major challenges at this mega city of Bangladesh.

\subsection{MANAGERIAL IMPLICATIONS}

The study would provide information to the government and concern authority for making necessary policies to overcome the coronavirus pandemic situation.

\subsection{LIMITATIONS OF THE STUDY}

This study only focused on the middle class people of Dhaka city. It did not include other classes of people and others area of Bangladesh. Another shortcoming of this study is that it did not show the solutions to overcome the situation.

\subsection{RECOMMENDATIONS FOR FUTURE RESEARCH}

This study has identified that the major challenges which are faced by middle class people at Dhaka city. It also shows the significant relationship between identified major challenges and coronavirus pandemic situation in collectively and individually. But this study did not include any kind of solutions to overcome the situation. Moreover, it did not include all the classes of the people and other cities and rural areas. These distinguish limitations could persuade future researchers for doing further research in this concern.

\section{REFERENCES}

[1] Coronavirus disease (COVID-19), World Health Organization(2020). https://www.who.int/healthtopics/coronavirus\#tab=tab_1

[2] Worldometer (2021). https://www.worldometers.info/coronavirus/

[3] Coronavirus COVID-19 Dashboard (2021), Directorate General of Health Services (DGHS). http://dashboard.dghs.gov.bd/webportal/pages/covid19.php 
[4] World Population Review. https://worldpopulationreview.com/world-cities/dhaka-population

[5] Shammi, M., Bodrud-Doza, M., Islam, A.R.M.T., Rahman, M. M. (2020). COVID-19 pandemic, socioeconomic crisis and human stress in resource-limited settings: A case from Bangladesh. Journal of Heliyon, 6(5). https://doi.org/10.1016/j.heliyon.2020.e04063

[6] Haque, M. N., Ansar, S. B., Biswas, G., Islam, M. R., \& Mamun, A. A. (2020). The Impact of COVID-19 on Socio Economic Condition of City People: Lessons From the Selected KCC Area. Journal of Engineering Science, 11(2), 117-126. https://doi.org/10.3329/jes.v11i2.50903

[7] Khan, I.M., Haque, U., Kaisar, S. Rahman M.S. (2020). A Computational Modeling Study of COVID-19 in Bangladesh. The American Journal of Tropical Medicine and Hygiene, 104(1), 66-74. https://doi.org/10.4269/ajtmh.20-0757

[8] USAID iMMAP/DFS COVID -19 situation analysis . Period: October 23 - November 30. Bangladesh COVID 19 Situation $\quad$ report November 2020. https://reliefweb.int/sites/reliefweb.int/files/resources/Bangladesh\%20COVID\%2019\%20Situation\%20report\% 20November\%202020.pdf

[9] Kabir, H., Maple, M. Usher, K. (2021). The impact of COVID-19 on Bangladeshi readymade garment (RMG) workers. Journal of Public Health, 43(1), 47-52. https://doi.org/10.1093/pubmed/fdaa126

[10] Anwar, S., Nasrullah, M., Hosen, M. J. (2020). COVID-19 and Bangladesh: Challenges and How to Address Them. Frontiers in Public Health, 8, 154. https://doi.org/10.3389/fpubh.2020.00154

[11] Bodrud-Doza, M., Shammi, M. Bahlman, L., Islam, A.R.M.T., Rahman, M.M. (2020). Psychosocial and SocioEconomic Crisis in Bangladesh Due to COVID-19 Pandemic: A Perception-Based Assessment. Frontiers in Public Health, 8, 341. https://doi.org/10.3389/fpubh.2020.00341

[12] Islam, M.S., Sujan, M. S. H., Tasnim, R. Sikder, M.T., Potenza, M. N., Van, J. (2020). Psychological responses during the COVID-19 outbreak among university students in Bangladesh. https://doi.org/10.1371/journal.pone.0245083

[13] Genoni M.E., Khan, A.I., Krishman, N., Palaniswamy, N, Raza, W. (2020). Losing Livelihoods: The Labor Market Impacts of COVID-19 in Bangladesh. https://openknowledge.worldbank.org/handle/10986/34449

[14] Hosen, I., Pakpour A.H., Sakib, N. Hussain, N. Mamun, F. A., Mamun, M. A. (2021). 10. Knowledge and preventive behaviors regarding COVID-19 in Bangladesh: A nationwide distribution. PLOS ONE, 16(5). https://doi.org/10.1371/journal.pone.0251151

[15] Begum, M., Farid, M.S., Barua, S., Alam, M. J. (2020). COVID-19 and Bangladesh: Socio-Economic Analysis Towards the Future Correspondence. Asian Journal of Agricultural Extension, Economics \& Sociology, 38(9), 143-155.

[16] Mottaleb, K.A., Mainuddin, M. , Sonobe, T. (2020) . COVID-19 induced economic loss and ensuring food security for vulnerable groups: Policy implications from Bangladesh. PLOS ONE, 15(10), e0240709. https://doi.org/10.1371/journal. pone.0240709 


\section{APPENDICES}

\section{Appendix 1 Communalities of the variables}

\begin{tabular}{|c|c|c|c|}
\hline $\begin{array}{l}\text { Sl. } \\
\text { No. }\end{array}$ & Name of the variables & Initial & $\begin{array}{l}\text { Extra } \\
\text { ction }\end{array}$ \\
\hline 1. & Most of the middle class people have lost their job & 1.000 & .587 \\
\hline 2. & $\begin{array}{l}\text { Unemployment among the middle class has risen due to the inability to re- } \\
\text { employ }\end{array}$ & 1.000 & .687 \\
\hline 3. & The change of profession has taken place more among the middle class & 1.000 & .423 \\
\hline 4. & The income of this class of people has decreased and they in financial crisis & 1.000 & .430 \\
\hline 5. & $\begin{array}{l}\text { In the case of middle class, migration from urban to rural areas has been more } \\
\text { frequent }\end{array}$ & 1.000 & .515 \\
\hline 6. & The ability of the middle class to meet the cost of education has decreased & 1.000 & .549 \\
\hline 7. & The middle class has been forced to reduce their daily basic needs & 1.000 & .606 \\
\hline 8. & The daily calorie intake of middle class people has decreased & 1.000 & .580 \\
\hline 9. & The standard of living among the middle class has declined & 1.000 & .482 \\
\hline 10. & $\begin{array}{l}\text { In order to meet the basic needs, the middle people of the city have fallen into } \\
\text { the vicious cycle of debt }\end{array}$ & 1.000 & .508 \\
\hline 11. & $\begin{array}{l}\text { People's purchasing power has declined due to the rising commodity prices and } \\
\text { lack of income }\end{array}$ & 1.000 & .434 \\
\hline 12. & The middle class has largely fallen below the poverty line & 1.000 & .439 \\
\hline 13. & Family unrest has increased in middle class families & 1.000 & .426 \\
\hline 14. & Child marriages has increased in middle class families & 1.000 & .578 \\
\hline 15. & Divorced has increased among middle class families & 1.000 & .660 \\
\hline 16. & The tendency to commit suicide has increased among middle class families & 1.000 & .630 \\
\hline 17. & $\begin{array}{l}\text { Corona has increased social distance increasing distance with relatives and } \\
\text { neighbors }\end{array}$ & 1.000 & .633 \\
\hline 18. & Frustration has increased among middle class people & 1.000 & .547 \\
\hline 19. & $\begin{array}{l}\text { There is a growing tendency among middle class people to become mentally } \\
\text { deranged }\end{array}$ & 1.000 & .530 \\
\hline 20. & $\begin{array}{l}\text { There is a growing tendency among the middle class youth to engage in } \\
\text { socially deviant behaviors such as theft, robbery, drug dealing etc. }\end{array}$ & 1.000 & .575 \\
\hline 21. & Savings have declined as the income of the middle class has declined & 1.000 & .557 \\
\hline 22. & Many families are not able to afford their children's online learning materials & 1.000 & .621 \\
\hline 23. & $\begin{array}{l}\text { Due to inability to meet the cost of education, dropout rate or education gap } \\
\text { has increased among the students of middle class families }\end{array}$ & 1.000 & .457 \\
\hline 24. & $\begin{array}{l}\text { Middle class school boys are looking for any job and joining. As a result, child } \\
\text { labor is increasing. }\end{array}$ & 1.000 & .461 \\
\hline 25. & Children are being deprived of sports which has increased their mental illness & 1.000 & .450 \\
\hline 26. & $\begin{array}{l}\text { School closures have increased children's addiction to video games and the } \\
\text { internet, which is detrimental to their mental and physical development }\end{array}$ & 1.000 & .399 \\
\hline 27. & $\begin{array}{l}\text { Among the middle class, the responsibilities towards parents and relatives have } \\
\text { decreased. }\end{array}$ & 1.000 & .369 \\
\hline
\end{tabular}


Appendix 2 Financial crises has led to increase child marriages and divorce due to increase family conflict

\begin{tabular}{|l|l|l|}
\hline Sl. No. & Name of the Variables & $\begin{array}{l}\text { Factor } \\
\text { Loadings }\end{array}$ \\
\hline 1. & Divorced has increased among middle class families & .804 \\
\hline 2. & The tendency to commit suicide has increased among middle class families & .772 \\
\hline 3. & Child marriages has increased in middle class families & .731 \\
\hline 4. & Family unrest has increased in middle class families & .447 \\
\hline 5. & $\begin{array}{l}\text { There is a growing tendency among the middle class youth to engage in socially } \\
\text { deviant behaviors such as theft, robbery, drug dealing etc. }\end{array}$ & .407 \\
\hline
\end{tabular}

Appendix 3 Failure to meet basic needs which reduced daily calorie intake that led to increase child labor

\begin{tabular}{|l|l|c|}
\hline $\begin{array}{l}\text { SI. } \\
\text { No. }\end{array}$ & Name of the Variables & $\begin{array}{l}\text { Factor } \\
\text { Loadings }\end{array}$ \\
\hline 1. & The daily calorie intake of middle class people has decreased & .690 \\
\hline 2. & The middle class has been forced to reduce their daily basic needs & .649 \\
\hline 3. & The ability of the middle class to meet the cost of education has decreased & .603 \\
\hline 4. & $\begin{array}{l}\text { Middle class school boys are looking for any job and joining. As a result, child } \\
\text { labor is increasing. }\end{array}$ & .590 \\
\hline 5. & Children are being deprived of sports which has increased their mental illness & .436 \\
\hline
\end{tabular}

Appendix 4 Unemployment rates and occupation changes have increased and the big number of people in debt has enhanced

\begin{tabular}{|l|l|l|}
\hline $\begin{array}{l}\text { Sl. } \\
\text { No. }\end{array}$ & Name of the Variables & $\begin{array}{l}\text { Factor } \\
\text { Loadings }\end{array}$ \\
\hline 1. & Unemployment among the middle class has risen due to the inability to re-employ & .766 \\
\hline 2. & Most of the middle class people have lost their job & .689 \\
\hline 3. & The change of profession has taken place more among the middle class & .552 \\
\hline 4. & The income of this class of people has decreased and they in financial crisis & .404 \\
\hline 5. & $\begin{array}{l}\text { In case of middle class, migration from urban to rural areas has been more } \\
\text { frequent }\end{array}$ & .404 \\
\hline 6. & $\begin{array}{l}\text { In order to meet the basic needs , the middle people of the city have fallen into the } \\
\text { vicious cycle of deb }\end{array}$ & .416 \\
\hline
\end{tabular}


Appendix 5 Decreased social interaction which led to increase psychological and physical complications among children and adults

\begin{tabular}{|l|l|c|}
\hline Sl. No. & Name of the Variables & $\begin{array}{l}\text { Factor } \\
\text { Loadings }\end{array}$ \\
\hline 1. & Savings have declined as the income of the middle class has declined & .702 \\
\hline 2. & $\begin{array}{l}\text { Corona has increased social distance increasing distance with relatives and } \\
\text { neighbors }\end{array}$ & .690 \\
\hline 3. & $\begin{array}{l}\text { School closures have increased children's addiction to video games and the } \\
\text { internet, which is detrimental to their mental and physical development }\end{array}$ & .473 \\
\hline 4. & $\begin{array}{l}\text { People's purchasing power has declined due to the rising commodity prices and } \\
\text { lack of income }\end{array}$ & .469 \\
\hline 5. & The income of this class of people has decreased and they in financial crisis & .430 \\
\hline
\end{tabular}

Appendix 6 Decreased financial ability of middle class people to meet the cost of education

\begin{tabular}{|l|l|l|}
\hline Sl. No. & Name of the Variables & $\begin{array}{l}\text { Factor } \\
\text { Loadings }\end{array}$ \\
\hline 1. & Many families are not able to afford their children's online learning materials & .661 \\
\hline 2. & $\begin{array}{l}\text { In the case of middle class, migration from urban to rural areas has been more } \\
\text { frequent }\end{array}$ & .582 \\
\hline 3. & $\begin{array}{l}\text { Due to inability to meet the cost of education, dropout rate or education gap has } \\
\text { increased among the students of middle class families }\end{array}$ & .574 \\
\hline 4. & $\begin{array}{l}\text { In order to meet the basic needs , the middle people of the city have fallen into the } \\
\text { vicious cycle of debt }\end{array}$ & .453 \\
\hline
\end{tabular}

Appendix 7 Frustration grows among the people that increased deviant behavior in the society

\begin{tabular}{|l|l|l|}
\hline Sl. No. & Name of the Variables & $\begin{array}{l}\text { Factor } \\
\text { Loadings }\end{array}$ \\
\hline 1. & Frustration has increased among middle class people & .632 \\
\hline 2. & $\begin{array}{l}\text { There is a growing tendency among middle class people to become mentally } \\
\text { deranged }\end{array}$ & .621 \\
\hline 3. & $\begin{array}{l}\text { There is a growing tendency among the middle class youth to engage in socially } \\
\text { deviant behaviors such as theft , robbery, drug dealing etc }\end{array}$ & .548 \\
\hline 4. & The standard of living among the middle class has declined & .428 \\
\hline
\end{tabular}

